\title{
MENDES, Luís Filipe de Castro. o jogo de fazer versos. Lisboa: Quetzal Editores, 1994.
}

Edgard Pereira dos Reis Universidade Federal de Minas Gerais

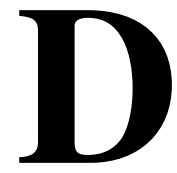

entre as inúmeras vertentes assumidas pela expressão poética no limiar da modernidade, destacase a postura voltada para as pesquisas de linguagem, ritmo e musicalidade incentivadas por Verlaine e abraçada pelos poetas simbolistas nas mais variadas latitudes. Em Portugal, Camilo Pessanha, Roberto de Mesquita e António Nobre são nomes tutelares de uma forma singular de aproximar palavras que encontra no Pessoa ortônimo uma referência importante, enquanto síntese de torneios e formas melódicas. Luís Filipe de Castro Mendes aproxima-se dessa maneira oblíqua, alusiva de exprimir a emoção. Os inúmeros envios a outros poetas (entre os quais, Camões, Pessanha, Teixeira de Pascoais, Pessoa, Rimbaud, Nuno Júdice, António Franco
Alexandre, Ezra Pound, Joaquim Manuel Magalhães) revelam o tributo a nomes tutela-res d' $O$ jogo de fazer versos, independente de sua maior ou menor inserção nos mais variados cânones. Aquilo que Fernando Pessoa fala a respeito de Pessanha pode se aplicar também a ele: para ser poeta não é necesário trazer o coração nas mãos, mas trazer nelas a sombra dele. O poema - essa partilha silenciosa - surge da consciência da linguagem como instância de encobrimento da subjetividade.

Surgida após a consolidação de um novo estatuto de poesia no contexto português pós-colonial - o que equivale a dizer: após a contenção da poesia 61, após a Poesia Experimental e após Cartucho-, a poesia de Luis Filipe Castro Mendes, especialmente no livro referido, 
articula-se, de forma amadurecida, aos jogos de citação e interlocução típicos dos anos 80. Entretanto - e esta se torna uma das suas mais interessantes marcas -, sua dicção poética se revela tendente a um rigor estrutural de efeitos melódicos e métricos, raro nos dias que passam:

Arregacei as mangas ao poema. A tudo fiz soneto: aqui, além... E nada em mim conheço que não [trema dum frio que não entende mais [ninguém.

Entender que a poesia subverte tudo o que a torna presa do instante; calar a própria dor, quando promete mais do que sabe o coração amante.

Ao referir o aspecto lúdico da atividade poética, o Autor nomeia o traço de aventura e risco que a acompanha. A elaboração lingüística resulta sempre recoberta por uma camada fluida de sonoridade que a rima liberta, ao invés de aprisionar. Ao se posicionar na atmosfera elegíaca da poesia dos anos 80, Luiz Filipe tem consciência da extensa rede que liga a melancolia a todas as manifestações poéticas portuguesas (seja sob a roupagem da saudade ou da mágoa), desde os trovadores medievais até a poesia contemporânea. Interessa ao poeta não apenas o registro da experiência subjetiva, mas o discurso dialógico a que as palavras de ordem e as canções da Utopia que erravam pelo ar na Lisboa inflamada dos idos de 1975 comparecem (Cf. o poema "Elegia").

O seu legado constitui o retorno às formas tradicionais $\mathrm{e}$ a partilha do cotidiano através das palavras, entre outras contribuições que, desde Ruy Bello e Herberto Hélder, possibilitaram à poesia portuguesa dialogar com a poesia européia contemporânea, sem prejuízo da especificidade do contributo ibero, alicerçado em séculos de experimentação lúdica da palavra:

Qualquer que seja a música sentida, nenhum poema dura se o não vê, essa razão que colhe dentre a vida outra apagada teia que nos lê. 